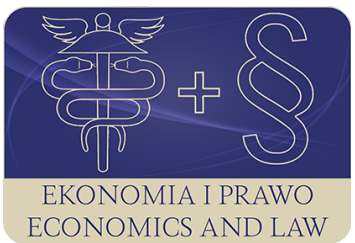

EKONOMIA I PRAWO. ECONOMICS AND LAW

Volume 19, Issue 3, September 2020

p-ISSN 1898-2255, e-ISSN 2392-1625

www.economicsandlaw.pl

EKONOMIA I PRAWO
ECONOMICS AND LAW

ORIGINAL ARTICLE

received 30.03.2019; revised 24.01.2020; accepted 30.09.2020

Citation: Zabielska, I. (2020). Cooperation, partnership and integration in the cross-border area: the role of borders and cross-border cooperation. Ekonomia i Prawo. Economics and Law, 19(3):

569-583. doi:10.12775/EiP.2020.038.

\title{
Cooperation, partnership and integration in the cross-border area: the role of borders and cross-border cooperation
}

\author{
IZABELA ZABIELSKA \\ University of Warmia and Mazury in Olsztyn, Faculty of Economic Sciences, Department \\ of Economic Policy, ul. Oczapowskiego 2, 10-719 Olsztyn, Poland \\ 曰izus@uwm.edu.pl \\ orcid.org/0000-0002-9421-7213
}

\begin{abstract}
Motivation: cooperation and partnership as an important tool that promotes cross-border integrations and stimulates the development of less developed border regions.

Aim: to determine the importance of partnership and cooperation in border areas. The theoretical part will define the role of borders and co-determination in the context of cross-border cooperation and integration. The empirical part - concentrates on examples of cross-border cooperation, distinguishing two main situations: borders between member states of the EU and borders between the EU and neighbouring countries.

Results: establishing transnational relations, and as a result partnership and cross-border integration, enables the flow and exchange of experience, knowledge and cooperation, thus affecting the economic development of cooperating regions.
\end{abstract}

Keywords: cross-border cooperation; partnership; integration; EU and non-EU borders; crossborder regions;

JEL: F15; F55; O19; P48

\section{Introduction}

Cooperation is a significant measure of building neighbourly relations, with cross-border cooperation being one of its components. Broadly interpreted, 
it brings about social-economic gains to all parties/partners taking part in it. Moreover, realized in a longer period of time, it leads to the integration of the cross-border region (compare: Decoville \& Durand, 2018, pp. 134-157; Giband \& Rufi, 2018, pp. 421-441; Scott et al., 2018, pp. 3-8). The assumed actions and undertakings strengthen and develop contacts, and enable the conclusion of agreements. As a result, they eradicate barriers where political and economic borders exist, while determining their sense (example of the Polish-Russian border). Cross-border partnerships, understood mainly through a prism of relations and cooperation, serve to build such 'openness'. They are usually supported by the European Regional Development Fund (ERDF) under programmes such as: Tasic, Phare CBC, Interreg or Cross-border Cooperation Programmes.

At the same time it ought to be emphasized that results achieved so far in the realization of cross-border projects and cooperation indicate their effectiveness (an example is, among others, the Polish-German border) and contribute to the integration of border regions.

As a result of the above, the author undertook the research topic which touches on the above-mentioned aspects. The aim of the work is, therefore, assessing the issues of partnership and cooperation in cross-border regions of the European Union. In the theoretical part, the essence of cross-border cooperation and partnership was determined, as well as their key elements. The empirical part focuses on examples of the implemented cross-border cooperation and partnership on the Polish-Russian as well as Polish-German border.

The author made use of preliminary and follow-up empirical research in her deliberations pertaining to cross-border cooperation and cross-border partnership.

Conclusion drawn from the studies can prove useful to, among others, potential partners of cross-border cooperation and project stakeholders, as well as those responsible for the integration and policy of sustainable development in cross-border regions.

\section{Literature review}

\subsection{Partnership and cross-border cooperation}

Cross-border collaboration in partnership creates the foundation for a cross-border network of connections enabling the cooperation between regions of various countries, with this ensuring the sharing of experience, and thus becoming a tool for obtaining and exchanging information. It therefore facilitates the development of universal economic and non-economic exchange. Moreover, it gives the opportunity to coordinate the development of infrastructure on both sides of national borders (Bruneckiene \& Sinkiene, 2015). Being an important promotional tool, it creates the possibility for the influx of investments, the de- 
velopment of tourism, exchange of ideas - especially concerning society, education and science, and enables culture-forming activities (see: Lipets, 2018, pp. 369-376). By removing social barriers, it initiates cross-border contacts, leading to increased trust among neighbours and building awareness of common interests (Greta \& Lewandowski, 2008, p. 224). As a measure of its quality we can consider, among others, active participation in initiating the implemented cross-border partnership; the frequency, nature and the permanence of bonds between members of societies on both sides of the border; even more so, considering that these partnerships differ in terms of their complexity (Pinelli, 2000). This is influenced by, among others, the shape and type of bonds, or the creators of cooperation implementing partnerships (scheme 1).

As follows from the above, the types of bonds connecting partners most differentiate partnerships at the beginning of cooperation. In partnerships based on formal bonds, personal relationships may appear (e.g. partners take part in various thematic celebrations); nevertheless, as compared to partnerships derived from personal relationships, these are more often occasional bonds, pertaining mainly to the leaders of the cooperation, less frequently observed among the remaining cooperating communities/entities. Partnerships based on personal bonds take on formal structures over time - a consequence requirement for taking advantage of public resources intended to support cross-border exchange and the practical effect of experiences of the cooperation as regards making use of these resources.

On the other hand, when the permanence of the partnership is concerned, the emergence of a partner motivated to realize cross-border cooperation becomes important. The atmosphere between the cooperating sides as well as attitude of the surroundings are also extremely important - this refers mainly to the support of local (also cross-border) entities and social perception of the cooperation.

An analysis of the objective scope of the cooperation assumed in these partnerships makes it possible to distinguish fields which the activities focus on; these are culture, tourism, recreation and sport, promoting leisure, cooperation of local governments, non-governmental organizations, the fire department, professional bodies, schools and associations, as well as mutual aid in the case of natural disasters. This also pertains to the exchange of experience connected with healthcare, social care, education, municipal services, water treatment plants or youth exchange, and, above all, the realization of common infrastructural undertakings, such as the building of roads, cycle paths.

It is once again worth emphasizing, that in order for cooperation to take place, the partnership of entities on both sides of the border is essential. This is seeing as how it is among the main principles of the operation and implementation of projects in EU member states (Council Regulation No. 1083/2006), and its financing takes place within the framework of European Territorial Cooperation (ETC) (treated as a separate aim of the cohesion policy) (Serwis Programów Europejskiej Współpracy Terytorialnej i Europejskiego Instru- 
mentu Sąsiedztwa, 2019). In the years 2014-2020, a budget which was focused on three models of cooperation was anticipated, and divided in the following manner:

- 74.05\% for cross-border cooperation and programs aiming to engage regions/local governments located near one of the borders (land or maritime);

- 20.36\% for transnational cooperation and programmes implemented in larger transnational territories;

- $5.59 \%$ for interregional cooperation and programmes aimed at increasing the efficiency of the cohesion policy.

Third countries can also participate in these programmes under resources from the European Neighbourhood Instrument (ENI) (Regulation EU No. 232/2014) - 15.4 billion euros and the Instrument for Pre-accession Assistance (IPA II).

Moreover, by means of the European Neighbourhood Policy (ENP), the EU cooperates with southern and eastern neighbours, supports stabilization, safety and well-being through cooperation initiatives: Eastern Partnership and Union for the Mediterranean (European Commission, 2019).

In the future, the ETC will most likely cover five issues:

- cross-border cooperation;

- cross-border cooperation and maritime cooperation;

- cooperation between of the most distant regions;

- interregional cooperation;

- interregional innovative investments.

It is also suggested that two aims regarding Interreg be distinguished: better Interreg management, and a safer and better protected Europe. The commission proposed granting 8.4 billion EUR for ETC 2021-2027 aims.

Currently, cross-border partnership is implemented in the framework of 7 indicated operational ETC programs pertaining to cross-border cooperation which include Poland (Poland-Slovakia, Czech Republic-Poland, Poland-Saxony, Brandenburg-Poland, South Baltic, Lithuania-Poland), and additionally 2 programmes from the European Neighbourhood Instrument (Poland-BelarusUkraine and Poland-Russia).

Therefore, in projects financed under EWT and EIS, a minimum of two entities from different counties must also be present, which enriches and, at the same time, makes their implementation difficult. This is seeing as how, on one hand, the partners differ in terms of just about everything: law, language, culture, history. Moreover, additional organizational outlays occur - more people, who ought to be coordinated, and this leads to a higher number of what are not always cohesive ideas, interests, visions, and a higher risk of coming across difficulties and the emergence of conflicts over the course of the project. On the other hand, they are connected by a common goal - that for which the project was created. That is why choosing the right members - partners become so important. 


\subsection{Partnership cooperation an important element of the development of border regions}

The above issues take on special significance when carrying out cross-border partner cooperation, also known as partner cooperation. Well, partnership cooperation ${ }^{1}$ according to Bareth - the founder of CEMR ${ }^{2}$ - can be considered as the 'meeting' and jointly undertaken actions aimed at strengthening and narrowing the neighbourly bonds of friendship ${ }^{3}$. This is a grassroots form of expressing European unity and identity, and the most visible form of cooperation between cities, communes and towns, emphasizing the fact of conducting contacts with foreign partners (Lechwar, 2008, p. 23). It is moreover activities based on the connection of local government units functioning on the base of an agreement to cooperate, informal contracts, letters of intent, or other forms of agreements (Szewczyk, 2007, p. 263). This is also such engagement which leads to creative solutions to problems affecting all of the partners (Grayson \& Hodges, 2004, p. 235). Finally, this is a voluntary relation, in which all participants (partners) agree to work together in order to reach a common aim or undertake a specific task, contributing their competence and resources, jointly take responsibility for and 'share' the advantages (European Commission, 2004; Kwatera \& Bukowska, 2009; Tennyson \& Wilde, 2000, p. 12).

What is important is that the above process is characterized by cooperation at the local or regional level, and forms the main segment of the European Neighbourhood Policy.

That is why partnership cooperation ought to be treated as a significant element of the development of border regions (Kmet \& Mayzner, 2017, pp. 182-199). This is seeing as how it supports activities aimed at increasing the competence with which governments and local government institutions operate (Zabielska, 2013, p. 46). Partnership contacts then pertain to, among others, the area of social integration (including cultural solidarity along with the arts) and sustainable development, or concentrate on youth exchange or taking advantage of local public services. Such cooperation therefore implies the long-term initiative of partners, not short-term cooperation in executing a given project ${ }^{4}$ (GUS, 1999). The so-formed partnership relations, cre-

${ }^{1}$ In the present work, partnership cooperation is also understood as the cooperation of partner regions and the cross-border cooperation realized on their land. That is why the terms will be used interchangeably in further parts of the work.

2 CEMR (Council of European Municipalities and Regions), was established in 1951 with the aim of building a united, peaceful and democratic Europe based on local and regional governmentalization. More at CEMR (2019a).

3 More at CEMR (2019b).

4 The cooperation of partner regions (cross-border) has been included among the EU priorities for years. Practically, since 1993, financial aid has been given under the Interreg programme - an instrument supporting cooperation between various entities operating in borderland areas. More at Interreg Europe (2019). 
ated from entering into contract, are often identified with twinning and give the possibility of the substitution of experience and unification in many spheres of life, as had already been mentioned in the present considerations. They are then understood as foreign contacts, the essence of which is the direct engagement of commune, district and province communities, as well as different local entities and organizations, in cooperation with communities on the other side of the border (Szewczyk, 2007, pp. 259-273). It is worth noting here that neither Polish state law nor international legislation clearly specifies the laws regarding such cooperation. Conditions which ought to be met in order for the cooperation between local government units of other countries (cooperating with each other) to be referred to as a twin relationship or partnership cooperation were also not specified; even more so considering that, in the current political-economic reality of Europe, the multidimensional cooperation of border regions has become a completely normal occurrence (Król \& Król, 2008, p. 43).

For this reason, partnership cooperation can be carried out in various formats and realized under: a cross-border project, cross-border partnership or bilateral cooperation.

Cross-border projects are concluded between cooperating partners (partnerships), who, upon preparation and approval by special organs, implement them in practice. They may occur in all fields of activity, while the initiated intentions bring about definite results - the so-called cross-border effect emerges, e.g. improving the economic structure, increase in employment or creating common products tagged with the brand of a given region (Palmowski \& Pacuk, 2004, p. 99).

Therefore, what we are dealing with here are such actions, that can lead to the elimination of differences and unification of the standard of living of citizens on both sides of the border, as well as eliminating problems connected with the forming of cross-border partnerships (Perkowski, 2010). This is seeing as how the partnerships, being a form of partnership cooperation, are included among the most important criteria of project operation and implementation in the EU. Thus, in accordance with this assumption, they can be assumed between the following in each member state (depending on the needs, legislation, and national practices):

- regional, local and city authorities, and other public authorities;

- economic and social partners;

- other appropriate entities representing the civil society.

A cross-border partnership covers all areas of social-economic life, and thanks to clearly defined aims as well as missions and visions, goes through the next stages of its formalization. There are: obtaining an appropriate partner, a partnership declaration, signing a partnership agreement and the contract regarding subsidization.

In order for the given partnership, after specifying the form of assuming cooperation, to be able to effectively realize aims, it must also determine rules which it will abide by in an effort to achieve the intended effects (e.g. equal rights 
of all partners, mutual benefits, long-term and innovative actions on a wide scale, the sharing of information and knowledge, seeking ways the elimination of disputes and mitigating conflicts) (Kantyka, 2010, p. 128).

Therefore, a cross-border partnership, treated as long-term cooperation, thanks to 'combining features and possibilities' characterizing individual partners, allows for solving various kinds of cross-border problems (from environmental, to social, local and even global), and thus gives new and better possibilities for development and the realization of bilateral cooperation. Twoway cooperation (e.g. cooperation between local government units with more than one partner) does not have to be assumed only in border countries, but can also be undertaken with countries located in distant areas. This is connected with the open possibility of taking advantage of European Union resources.

\section{Methods}

The author used qualitative studies and empirical research to achieve the aims of the work. The study is primarily an analysis of available literature, other materials and other research related to the issues of cross-border cooperation and partner cooperation, as well as cross-border partnerships. The conclusions of these studies are presented in the previous and subsequent parts of these considerations.

Qualitative research has included two types of areas located near the state border as a model view of cross-border integration. One of them located inside the EU borders (Polish-German border). The second - on the external border of the EU (Polish-Russian border).

In the case of the Polish-German border, the following research was used: (1) directed (using an structured interview technique) to Polish (50 interviews) and German (20 interviews) leaders (people) involved in the creation and development of cross-border partnerships and only focus on cooperation in the Euroregion Spree-Nysa-Bóbr (Frątczak-Müller \& Mielczarek-Żejmo, 2014); (2) carried out in 2016 and 2017 by means of individual in-depth interviews (Kurowska-Pysz \& Walencik, 2017), which included organizations (30 respondents) participating in at least two completed cross-border projects co-financed by the Interreg program, i.e. local governments, public institutions and non-governmental organizations.

In turn, for the purpose of qualitative research on the Polish-Russian border, an interview questionnaire (direct survey) was prepared for people responsible for cross-border contacts in 33 Polish border communes (in the border area of the Warmia-Mazury Voivodeship). The research carried out by the author in 2017 focused on the specificity of the partnership and cross-border cooperation with the Kaliningrad region of the Russian Federation (an EU external border and a NATO border). They were implemented under the following programs: Tacis, Phare CBC, Interreg or the Cross-Border Cooperation Program Lithuania-Poland-Russia 2007-2013 and Poland-Russia 2014-2020. 
With regard to the research problem, the author also defined the benefits and barriers to partnership and cross-border cooperation between Poland and Germany as well as Poland and Russia.

\section{Results}

Forms of cross-border integration vary form one cross-border area to another. In the view of the Council of Europe, they result from a combination of two parameters: decision and policy choices made jointly by local, border partners, together with the legal avenues available to them under domestic law and international undertakings entered into by the states to which they belong (Slusarciuc, 2013, p. 269). Many of the partnerships have been inducted informally, based on plans for cross-border activities of participants in such co-operation.

In order for cooperation to take place, as has already been emphasized in the present deliberations, partnership between entities on both sides of the border must occur. It can also be proven that the existence of a partnership is confirmation of the existence of cooperation (Szmigiel-Rawska \& Dołzbłasz, 2012). Such cooperation becomes an important element of borderland and cross-border integration. The latter is most often carried out in the terms of providing services, exchanging raw materials and goods, scientific-development and tourism-related activity, as well as environmental protection and spatial planning in border areas (Zabielska, 2013). As a result, cross-border integration pertains mainly to: (1) horizontal partnership and refers to the relationships between partners in cross-border areas and (2) long-term cooperation, and is based on many-year action plans; therefore, the taking down of barriers resulting from the existence of national borders becomes of essence. The lack of steps whatsoever taken in this direction can threaten the development of international relations as well as halt the processes at cross-border regions.

At the same time, two situations ought to be differentiated between: a border between EU member states (cooperation within EU borders) and between the EU and third countries (cooperation outside EU borders). In the first case, the societies of near - border regions mutually explore the development of the cooperation policy and partnership, and find solutions for common challenges. In the second - the border regime and Schengen code pose difficulties in realizing cooperation (research on Polish-German and Polish-Russian relations in the context of their difficult history - World War II and communist oppression - and the process of reconciliation between nations in: Penczek-Zapala \& Boski, 2015, pp. 100-109).

Integration and Polish-German cross-border cooperation (compare: Petersen, 2018) can be considered an exemplary model of cooperation and partnership, despite historical events which are deeply embedded in the memories of the inhabitants of this region. The analysis of this partnership allows us to draw a few significant conclusions, as shown in table 1 . 
Polish-German cooperation can be used as a model for regions on the eastern border of the EU, for example on the Polish-Ukrainian or Polish-Russian border.

Polish-Russian cooperation emerged on the grounds of numerous systemic, historical, psychosocial and political differences (compare: Koch, 2018, pp. 115133). Nevertheless, the geographical proximity makes it possible to develop various forms of economic relationships and mutual contacts, facilitating solutions which are beneficial to both sides. An example of this are the relations with the Kaliningrad Oblast RF, despite the fact that they were restricted for political reasons until the end of the 80 s of the 20th century. The oblast at the time held the status of a militarily special zone, and the closed nature of the border made free cooperation impossible - limited and formalized contacts determined by ideological factors. It was not until the changes in the 80s and 90s of the 20th century that the forming of cross-border relations ${ }^{5}$ was facilitated. For Poland and its border areas, the Oblast is an important area when it comes to geopolitics and geo-economics. Mutual cooperation becomes important in a bilateral and multilateral dimension, taking into account European and Transatlantic integration processes.

The analysis of Polish-Russian partnerships also shows (table 1) that the project did not interfere in their development, but also did not particularly influence the frequency of cooperation (e.g. high frequency prior to and following the implementation of the project, and low during its course). This may stem, among others, from the fact of establishing subsequent partnerships and, under them, further activities, and implementing further cross-border partnerships; or taking advantage of participation to obtain funds - intense cooperation over the course of preparing documentation and the lack of participation in the effects of implemented projects.

Administrative-legal barriers, the lack of financial resources (especially on the Russian side), limited access to information on the Russian partner, difficulties in finding cross-border partners or the lack of support from the state are the main obstacles in the implementation of a Polish-Russian cross-border partnership. Moreover, further attributing to this is the high instability in the functioning of the border connected with the immense influence of political relationships between NATO and the EU on one side, and Russia on the other.

\section{Conclusion}

It follows from the studies that the implementation of a cross-border partnership under European Territorial Cooperation in the component of cross-border cooperation only confirms the high significance of such activity. What is more, continuation in individual periods of programming makes it possible to claim

5 Agreement on cooperation between the Olsztyn Voivode and the leader of the Kaliningrad Oblast RF administration. 
that it is becoming necessary to the realization of the cohesion policy, and above all cross-border integration. This is significant not only from the perspective of border areas located within the borders of the EU (e.g. the Polish-German border) but also those which are located on the external EU borders (e.g. the Polish-Russian border).

The research presented on the Polish-German and Polish-Russian border furthermore show that cross-border partnerships, building tolerance and acceptance among diverse societies, lead to respecting the differences of other cultures. The established cooperation then becomes an instrument for expanding and developing contacts and informal networks of cross-border relations, the promotion of regions as well as exchanging experience. Not without significance, where the border area local economy is concerned, is also the potential exchange or possibility of obtaining foreign partners. Cross-border programmes are to support this; however, as results from the research, in order for them to contribute to taking proper actions and solving significant cross-border problems, they should concentrate solely on long-term relationships. The institutionalization of cooperation then takes place - signing partnership contracts, creating partnerships, or other means of formalizing and perpetuating relationships are created.

However, what ought to be emphasised, the participants of the in-depth surveys referred to in this publication were not able to confirm the division of partnerships into: (1) non-formal with a weak intensity and (2) formal 'networks' with a strong area of influence and systematic nature of assumed activities. This is seeing as how they claimed that these ties (formal and informal) are interconnected with one another; even more so when considering the fact that the natural consequence of cooperation is the crystallization of a partnership, while its emergence is essential to the willingness to make use of resources attributed to projects. On the other hand, the formal structure gives birth to a network of natural informal connections.

Analyses of research also indicate the occurrence of important barriers in creating partnerships, and these are:

- incidental, one-time partnership (not resulting from actual needs) calculated of obtaining EU funding (without permanence);

- typical partnerships (e.g. between local governments, cultural entities; low inclination for intersectoral partnership);

- partnership focused on institutions (entities) realizing the project not on the needs of their stakeholders;

- partnerships that are 'above' one of the participants;

- partnerships fitted to the needs and conditions of only one of the parties.

At the same time, one must keep in mind that establishing and continuing permanent cooperation in subsequent projects depend on the quality of this partnership in the scope of its preparation and realization. In order to achieve this, the analysed cooperation leaders indicate, above all, the strengthening of partnerships by getting to know each other and building good-neighbour 
bonds. This allows for the better coordination of strategic projects, more effective absorption of resources from EU funds, better preparation and implementation of projects and permanent results of partnerships.

The presented studies, in which an analysis of the state of the Polish-German and Polish-Russian partnership is provided, make it possible to recommend directions to stimulate future cooperation, which is an element of cross-border:

- the existing partnerships ought to be expanded to include new entities/institutions (intersectoral partnerships; but not only bilaterally);

- the seeking out of new subjects of cooperation becomes necessary.

Proper cross-border cooperation generates key effects in the project for the partners: (1) synergy effect (better results achieved together than individually); (2) the area of influence (common results of mutual actions - greater area of influence on a larger group of recipients than in the case of individual effects); (3) resources ('common' resources - skills, knowledge, experience, staff, financial resources, etc. - enable more effective action).

\section{References}

Bruneckiene, J., \& Sinkiene, J. (2015). The economic competitiveness of Lithuanian-Polish border region's cities: the specific of urban shrinkage. Equilibrium. Quarterly Journal of Economics and Economic Policy, 10(4). doi:10.12775/ EQUIL.2015.039.

CEMR. (2019a). Retrieved 20.12.2019 from https://www.ccre.org.

CEMR. (2019b). Retrieved 15.01.2019 from: http://www.twinning.org.

Council Regulation (EC) No 1083/2006 of 11 July 2006 laying down general provisions on the European Regional Development Fund, the European Social Fund and the Cohesion Fund and repealing Regulation (EC) No 1260/1999 (OJ L 210, 31.7.2006).

Decoville, A., \& Durand, F. (2018). Exploring cross-border integration in Europe: how do populations cross-borders and perceive their neighbours? European Urban and Regional Studies, 26(2). doi:10.1177/0969776418756934.

European Commission. (2004). Communication from the Commission to the Member states of 2 September 2004 laying down guidelines for a Community initiative concerning trans-European cooperation intended to encourage harmonious and balanced development of the European territory: Interreg III (OJ C 226).

European Commission. (2019). European neighbourhood policy and enlargement negotiations. Retrieved 20.12.2019 from https://ec.europa.eu.

Frątczak-Müller, J., \& Mielczarek-Żejmo, A. (2014). Cross-border partnerships: institutions in initiating social networks (based on the Euroregion Spree-NiesseBober). Opuscula Sociologica, 9(3).

Giband, D., \& Rufi, J.V. (2018). European cross-border spaces: a difficult to define geographic object? An approach from the perspective of soft spaces. Documents d Analisi Geografica, 64(3). doi:10.5565/rev/dag.520. 
Grayson, D., \& Hodges, A. (2004). Corporate social opportunity: 7 steps to make a corporate social responsibility work for your business. Sheffield: Greenleaf.

Greta, M., \& Lewandowski, K. (2008). The significance of euroregions in the process of achieving social and economic cohesion in the European Union. In: R. Stanisławski, M. Greta, \& A. Maciaszczyk (Eds.), Structural funds for the socio-economic development of the Lodz region in the perspective of experiences of Polish regions. Eódź: Politechnika Łódzka.

GUS. (1999). Euroregiony w nowym podziale terytorium Polski. Retrieved 20.12.2019 from http://www.sbc.org.pl.

Interreg Europe. (2019). Retrieved 20.12.2019 from https://www.interregeurope.eu.

Kantyka, S. (2010). Partnerstwo lokalne w kontekście idei zrównoważonego rozwoju. In: A. Frączkiewicz-Wronka (Ed.), Partnerstwo lokalne jako strategia rozwiązywania problemów spotecznych. Katowice: Katowice University of Economics.

Kmet, E.B., \& Mayzner, N.A. (2017). The methodical approach to the evaluation of the competitiveness of the border territories. European Research Studies Journal, 20(2B). doi:10.35808/ersj/673.

Koch, K. (2018). The role of territoriality in the European Union multi-level governmental cooperation framework of Finnish-Russian cross-border cooperation. European Urban and Regional Studies, 26(2). doi:10.1177/0969776417736359.

Król, M.J. \& Król P. (2008). Scenariusze rozwoju współpracy transgranicznej po akcesji Polski do Unii Europejskiej: przypadek podkarpackiego pogranicza polsko-ukraińskiego. In: M.G. Woźniak (Ed.), Spójność spoteczno-ekonomiczna a modernizacja regionów transgranicznych. Rzeszów: Uniwersytet Rzeszowski.

Kurowska-Pysz, J., \& Walencik, M. (2017). Cross-border partnership: the approach in the projects co-financed by European Union funds. In M. Boda (Ed.), Proceedings of the Faculty of Economics of Matej Bel University in Banská Bystrica: Economic Theory and Practice 2017. Banska Bystrica: Belianum.

Kwatera, K., \& Bukowska, R. (2010). „Partnerstwo w Leadarze” o wspótpracy i sieciowaniu LGD. Kraków: Małopolska Sieć LGD.

Lechwar, M. (2008). Instytucjonalne podstawy europejskiej współpracy transgranicznej. In: M.G. Woźniak (Ed.), Spójność spoteczno-ekonomiczna a modernizacja regionów transgranicznych. Rzeszów: Uniwersytet Rzeszowski.

Lipets, E.Y. (2018). Dialogue of cultures in the context of globalization: an ethnic aspect. European Research Studies Journal, 21(2).

Palmowski, T., \& Pacuk, M. (Eds.). (2004). Europa Battycka regionem wspótpracy i integracji. Gdańsk-Kopenhaga: Katolickie Stowarzyszenie Civitas Christiana, Związek Miast i Gmin Morskich.

Penczek-Zapala, M., \& Boski, P. (2015). Difficult neighborhoods: wrestling with the history of Polish-German and Polish-Russian relations. Ceskoslovenska Psychologie, 59. 
Perkowski, M. (Ed.). (2010). Wspótpraca transgraniczna: aspekty prawno-ekonomiczne. Białystok: Fundacja Prawo i Partnerstwo.

Petersen, H.G. (2018). Europäische Werte im Konflikt mit Neo-Nationalismus: Europa zwischen fortschreitender Integration und Exit-Optionen. Paper presented at the Deutsch-Georgisches Wissenschafts- und wirtschaftsforum, May 15-18, 2018, Berlin, Germany.

Pinelli, D. (2000). Regional competitiveness indicators. In: M. Klamot, \& L. Cybulski (Eds.), Polityka regionalna i jej rola w podnoszeniu konkurencyjności regionów. Wrocław: AE we Wrocławiu.

Regulation (EU) No 232/2014 of the European Parliament and of the Council of 11 March 2014 establishing a European Neighbourhood Instrument (OJ L 77, 15.3.2014).

Scott, J.W., Celata, F., \& Coletti, R. (2018). Bordering imaginaries and the everyday construction of the Mediterranean neighbourhood: introduction to the special issue. European Urban and Regional Studies, 26(1). doi:10.1177/0969776418795208.

Serwis Programów Europejskiej Współpracy Terytorialnej i Europejskiego Instrumentu Sąsiedztwa. (2019). Retrieved 20.12.2019 from http:/ / www.ewt. gov.pl.

Slusarciuc, M. (2013). Partnership and cooperation models in cross-border areas the role of borders and cross-border cooperation. Acta Universitatis Danubius. Oeconomica, 9(4).

Szewczyk, J. (2007). Zagraniczne związki partnerskie polskich samorządów miast, powiatów i województw. Prace Geograficzne: Instytut Geografii i Gospodarki Przestrzennej Uniwersytetu Jagiellońskiego, 117.

Szmigiel-Rawska, K., \& Dołzbłasz, S. (2012). Trwatość wspótpracy przygranicznej. Warszawa: CeDeWu.

Tennyson, R., \& Wilde, L. (2000). The guiding hand: rokering partnerships for sustainable development. New York: UN.

Zabielska, I. (2013). Transgraniczna współpraca regionów. In R. Kisiel, \& M. Wojarska (Eds.). Wybrane aspekty rozwoju regionalnego. Olsztyn: Fundacja Wspieranie i Promocja Przedsiębiorczości na Warmii i Mazurach.

Zabielska, I., \& Zielińska-Szczepkowska, J. (2013). Koszty-korzyści wejścia w życie umowy o matym ruchu granicznym z Obwodem Kaliningradzkim FR: wyniki badań ankietowych. Retrieved 20.12.2019 from http://eurobalt.org.pl.

\section{Acknowledgements}

Author contributions: author has given an approval to the final version of the article.

Funding: this research was funded by the University of Warmia and Mazury in Olsztyn, Faculty of Economic Sciences statutory sources.

Note: the results of this study were presented at 10th International Conference on Applied Economics Contemporary Issues in Economy (June 27-28, 2019, Torun, Poland). 


\section{Appendix}

Table 1.

\section{Cooperation, integration and cross-border partnership of EU internal and external borders}

Polish-German border

- among the participants of partnerships who carry out Polish-German cross-border projects (carried out under Interreg), distrust and prejudices have been substantially offset and do not constitute barriers. During cross-border cooperation, a context specific to social networks is created — participants exchange experience and ideas;

- analysis of project applications shows that Polish institutions are more likely to act as leading partners, which may be confirmation of accepting organizational responsibilities, but also — indirectly indicates Poles as the initiators of most project;

- lower interest of German institutions in the implementation of joint projects can probably be explained by the saturation of the share realized in other (than with Poland) programs (including the US, Great Britain or France);

- knowledge of the neighbour's language becomes a condition for the implementation of Polish-German partnerships - Poles who know German most often become the leaders;

- lack of continuators for cooperation and implementation of cross-border partnerships (e.g. the leaving or retirement of leaders) leads to their extinction;

- Euroregions and European groupings of territorial cooperation functioning in this area can play an important role in the future in the integration of borders, mainly because it is a border between EU member states;

- a change in the structure of cross-border projects is recommended, with more focus on economic and social integration and less on infrastructure;

- cross-border cooperation programmes can cause polarization within the border area;

- cooperation and networking frontier communities of the two countries develops more than the cross-border area, which constitutes a deeper and complementary level of collaboration considered to be a support for cultural European West Axis reinforcement;

- the Polish-German border is considered an internal EU border — connecting rather than dividing different and mutually complementary economic, cultural and social systems;

Polish-Russian border

- activity under a cross-border partnership (lasting, on average, from 5 to 15/20 years, with the majority up to 5 years - due to the permanence of the project) is expressed among others, in the: official visits of representatives of local authorities and institutions and studio visits; formalized constant partnership (on the basis of a contract/letter of intent e.g. the partner city/commune, town twinning); project partnership; common engagement on various planes of cooperation;

- the Polish-Russian partnership is carried out: on the basis of bilateral or multilateral contracts; under the framework of Euroregions: Baltic, Niemen;

- Polish-Russian cross-border partnership develops in the fields of culture, education, sport, tourism and interpersonal contacts.;

- the most important motives for participation in cross-border projects pertain to: the creation and development of border area infrastructure, supporting entrepreneurs in establishing contacts and strengthening existing cross-border relations as well as possibilities of mutually applying for EU financial aid (cross-border projects were supported by: Tacis, Phare CBC, Interreg or Lithuania-Poland-Russia Cross-Border Cooperation Programme 2007-2013 and Poland-Russia 2014-2020);

- activities commonly assumed by partners upon finishing a cross-border project often became a direct extension of cross-border activity;

- an impulse for livening the development of cooperation in the area of Polish-Russian partnership was establishing, in 2012, a local border traffic zone (LBT)* (terminated as of July 2016 on grounds of national security) due to the proximity of the border; a convenient communication system; involvement of local society and entrepreneurs in maintaining various contacts with foreign partners;

- the project did not interfere in their development, but also did not particularly influence the frequency of cooperation (e.g. high frequency prior to and following the implementation of the project, and low during its course);

Notes:

* As part of the LBT, the author (as a co-author) analyzed the benefits and losses (on the Polish side and on the Russian side) after the intrOduction of the Polish-Russian agreement (survey studies conducted among residents, entrepreneurs and local government units. More in Zabielska \& Zielińska-Szczepkowska (2019).

Source: Own preparation based on Frątczak-Müller \& Mielczarek-Żejmo (2014, pp. 52-53); Slusarciuc (2013, pp. 274-275), Zabielska (2013, pp. 46-71). 


\section{Scheme 1.}

Variants of partnership and cross-border links

type of bond

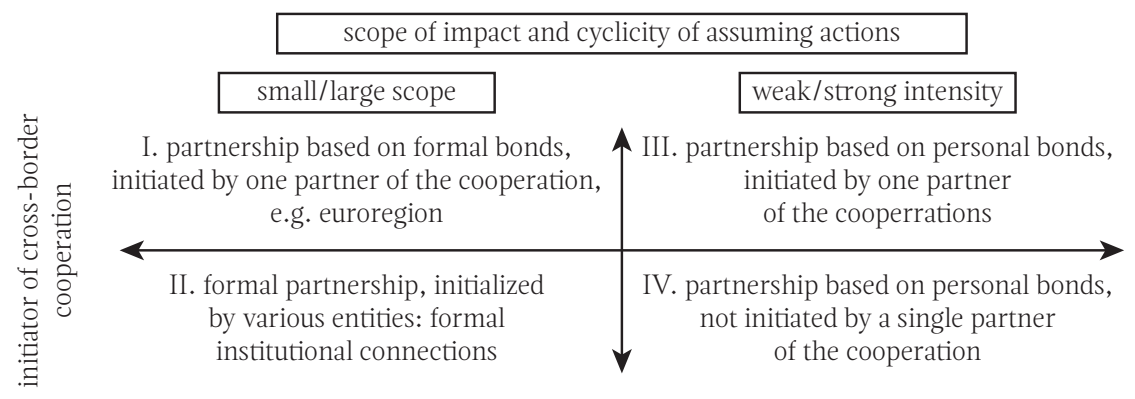

Source: Own elaboration based on Frątczak-Müller \& Mielczarek-Żejmo (2014, p. 50). 
